\title{
Predictors of willingness to pay for physical activity of socially vulnerable groups in community-based programs
}

\author{
Marion C. Herens ${ }^{1 *}$, Johan A. C. van Ophem², Annemarie M. A. E. Wagemakers ${ }^{1}$ and Maria A. Koelen ${ }^{1}$
}

\begin{abstract}
Willingness to pay (WTP) is used to assess individuals' value attribution to health-related quality of life interventions. Little is known about predictors of WTP for sport and physical activity in socially vulnerable groups in communitybased physical activity (CBHEPA) programs. This study addresses the questions: What is the WTP for sport and physical activity of participants in CBHEPA programs, expressed in WTP money and WTP time $_{\text {? }}$ Which factors predict WTP money and WTP time? From the literature, predictors for WTP for sport and physical activity were identified: (1) personal and socioeconomic predictors: income, education, age, and ethnic origin, (2) health-related predictors: perceived health, life satisfaction, sense of coherence, self-efficacy, (3) sport and physical activity-related predictors: duration and frequency of participation, leisure-time sport or physical activity, sport club membership, enjoyment, and membership fee. Data were gathered for WTP money and WTP time $(n=268)$ in 19 groups in an evaluation study of CBHEPA programs. Ordered probit was used for analyses. WTP money was a monthly average of $€ 9.6$. WTP time was on average 17.6 min travel time. Income was found as predictor for both WTP money and WTP time. Other predictors for WTP money were: duration and frequency of program participation, enjoyment, and (former) sport club membership. Low income and younger age were found as predictors for WTP time. Predictors for WTP money are related to income and sport and physical activity experiences, for WTP time to income and age. Short-term program satisfaction is probably more decisive for WTP money than long-term perspectives of improving health-related quality of life.
\end{abstract}

Keywords: Sport and physical activity, Community-based, Willingness to pay, Socially vulnerable groups, Health-related quality of life

\section{Background}

Physical inactivity has been identified by the World Health Organisation as the fourth leading risk factor for global mortality, causing globally an estimated 3.2 million deaths per year (GAPA 2012; WHO 2012). Health disorders associated with inactivity, including impaired health-related quality of life as well as direct and indirect economic costs, exert a substantial burden on societies and health systems (Craig et al. 2012). In the Netherland, socially vulnerable groups, e.g. those with low socio-economic status (SES), unemployed or of non-Dutch origin,

\footnotetext{
*Correspondence: marion.herens@wur.nl

1 Social Sciences Group, Chair Group Health and Society, Wageningen University and Research, Hollandseweg 1, Postbus 8130, 6700 EW Wageningen, The Netherlands

Full list of author information is available at the end of the article
}

are less engaged in sport and physical activity than higher SES groups (Wendel-Vos et al. 2009; Hildebrandt et al. 2013). In response to the observed inequalities, Dutch policy has been to promote community-based healthenhancing physical activity (CBHEPA) programs in order to improve the health and wellbeing of socially vulnerable groups (Ministry of Health Welfare and Sports 2006, 2012). Approximately $€ 60 \mathrm{~m}$ are spent on campaigns, research, and institutions to promote healthy and active lifestyles, and healthy social and physical environments (Post et al. 2010; De Wit et al. 2010). In 2010 (local) sports-related government expenditures were ca. $€ 3.5 \mathrm{bn}$, spent on exploitation costs, maintenance of sports facilities and subsidy schemes enhancing sport and physical activity (Centre for Policy-related Statistics 2013). A substantial portion of the subsidy schemes is dedicated

\section{Springer}


to enhancing physical activity behaviour in socially vulnerable groups. Not much is known, however, about the extent to which socially vulnerable groups themselves are able and willing to invest in sport or physical activity in order to achieve active and heathy lifestyles.

Over the past two decades, the contingent valuation method (CVM) asking people's stated preferences for a good or a health service (Morris et al. 2007), is being used more often in health economics research to assess value attribution at individual level to health-related quality of life interventions (Klose 1999; Donaldson and Shackley 2003; Drummond et al. 2005; Olsen et al. 2004; Cawley 2004; Lorgelly et al. 2010; Murphy et al. 2012). CVM assumes a direct relationship between the amount of money or time invested and the health benefits experienced (Borghi and Jan 2008). Assessment of willingness to pay (WTP) is a relatively easy CVM to study perceived benefits at individual level of CBHEPA programs. WTP reflects the extent to which people are willing to pay for positive health improvements (Drummond et al. 2005; Remonnay et al. 2008). Usually, WTP is expressed in monetary terms ( $\left.\mathrm{WTP}_{\text {money }}\right)$. Willingness to spend time travelling to sport and physical activity ( $\left.\mathrm{WTP}_{\text {time }}\right)$ which in transportation models is seen as a disutility that should be minimised-should be regarded as an additional estimator of positive value attribution (Dijst and Vidakovic 2000), since it expresses willingness to make an effort to participate.

Relevant literature on WTP for recreational sport and physical activity is, however, fairly limited. Johnson et al. (2007) argued that published CVM studies of sports public goods have mostly focused on WTP for professional or spectator sports. The fact that governments also subsidise other sport and physical activities, such as amateur and recreational sport or CBHEPA programs, is usually not taken into account. The underlying idea of these subsidy schemes is that participation in sport and recreational physical activities is supportive to the development of social capital by contributing to community bonding, hence enhancing quality of life in a community (Putnam 2000; Lindström et al. 2001; Skinner et al. 2008). It may also improve the health and well-being of participants and reduce health-care costs (Hawe and Shiell 2000; Johnson et al. 2007).

In view of these expected societal benefits, it is unclear whether predictors for WTP for health improvements also predict WTP for sport and physical activity in CBHEPA programs. In this study we use WTP as a particular measure to assess value attribution to the experienced benefits of CBHEPA programs by individual participants, in addition to physical activity and healthrelated outcome measures, in order to contribute to a broader recognition of the (non)sense of government investments in CBHEPA programs. In order to assess the capacity and willingness to invest in sport and physical activity of socially vulnerable groups, our study addresses the following questions: What is the WTP for sport and physical activity of participants in CBHEPA programs in terms of money and time (WTP $\left.\mathrm{Woney}_{\text {and }} \mathrm{WTP}_{\text {time }}\right)$ ? Which factors predict $\mathrm{WTP}_{\text {money }}$ and $\mathrm{WTP}_{\text {time }}$ ?

\section{Predictive factors for WTP for sport and physical activity}

Little is known about predictors for WTP for sport and physical activity. WTP values drawn from a CVM survey are determined by personal and behavioural characteristics of the respondent and characteristics of the service specified (Smith 2003). Regarding personal and behavioural characteristics, studies on WTP for health improvements indicate that personal and socio-economic factors as well as health-related quality of life factors are relevant predictors (Bauman et al. 2002; Hagger et al. 2002; Rhodes et al. 2007). Regarding service characteristics, sport and physical activity behaviour and program-related factors may be relevant predictors. For our study, we assume that factors predicting health-related quality of life may be relevant for predicting WTP for health improvements, and factors predicting WTP for health improvements may be relevant for WTP for sport and physical activity.

1. Personal and socio-economic predictors relate to an individual's non-behavioural conditions, setting the boundaries for individual demand. Some studies suggest that WTP is positively related to income (Donaldson et al. 1997; Romé et al. 2010), others report no significant relationships (Johannesson and Johansson 1997; Olsen and Smith 2001). In line with a utilitarian perspective, WTP for sport and physical activity is expected to increase with increasing income. Some studies also suggest that WTP is positively related to educational level (Romé et al. 2010). More highly educated people are generally more health literate, i.e. more knowledgeable on healthy lifestyles and potential risk factors (Ross and Wu 1995). Some studies suggest that WTP is negatively related to age, indicating that older people are less willing to pay for health improvements than younger people (Johannesson and Johansson 1997; Krupnick et al. 2002; Romé et al. 2010). In addition, socially vulnerable groups tend to become less healthy and active with increasing age (WHO 2006; Cockerham 2007). Studies on the relation between WTP and ethnic origin seem scarce. A negative relationship between WTP and ethnic origin can be assumed, since ethnic origin is related to impaired health (Bos et al. 2004; Pampel et al. 2010) and higher levels of physical inactivity (Crespo et al. 2001; Hildebrandt et al. 2013). 
2. Health-related quality of life predictors relate to an individual's behaviour and perceived health benefits. Although many instruments, consisting of different components, have been developed to measure health-related quality of life (Bowling 2005), less is known about the relation of each component to WTP for health improvements or sport and physical activity. Components of health-related quality of life that may be relevant for WTP for sport and physical activity are perceived health status (Rütten et al. 2001; Van Stralen et al. 2009), life satisfaction (Downward and Rasciute 2011; Lehnert et al. 2012), the ability to cope with life stressors (Antonovsky 1996; Van Stralen et al. 2009), and self-efficacy relating to physical activity behaviour (Marcus et al. 1992; McAuley and Blissmer 2000; Nickel and Spink 2010). Several studies suggest a positive relationship between WTP for health improvements and perceived health status (Donaldson and Shackley 2003; Bayoumi 2004; Borghi and Jan 2008; Victoor et al. 2012), whereas others report no significant relationships (Donaldson 1999). A positive relationship between WTP for health improvements and life satisfaction can be expected, since life satisfaction is positively related to health-related quality of life and physical activity. Furthermore, we expect a positive relationship between WTP for health improvements and the ability to cope, or sense of coherence (SoC). SoC relates to the way people cope with life stressors and is highly correlated with health-related quality of life (Eriksson and Lindström 2007). Similarly, we expect a positive relationship between WTP and self-efficacy, i.e. one's confidence in one's ability to manage and succeed in specific situations (Bandura 1995), since previous studies show that self-efficacy is positively related to health-related quality of life and physical activity (Marcus et al. 1992; McAuley and Blissmer 2000; Hagger et al. 2002; Bauman et al. 2002; Van Stralen et al. 2009). To our knowledge, however, no previous studies include life satisfaction, sense of coherence, or self-efficacy in WTP research.

3. Sport and physical activity-related predictors relate to individual behaviour in relation to CBHEPA program characteristics. Recreational literature based on experience use theory suggests that WTP is positively related to duration and frequency of participation in a certain activity or program (Kyle et al. 2006; LópezMosquera and Sánchez 2013). Some studies suggest that WTP is positively related to experiences in leisure-time sport and (former) sports club membership (Pawlowski et al. 2009; Prins et al. 2010; Downward and Rasciute 2011). People who are or were member of a sport club are more willing to pay for leisure- time sport and physical activity than people with no history in sports (Bauman et al. 2002), and are good estimators of the costs. McCarville (1991) indicates that the level of membership fee can be regarded as the reference fee. In our study, we also include enjoyment as a variable, since some studies suggest that people engage in sport and physical activity for pleasure rather than for health benefits (Henderson 2009; Mullen et al. 2011). Therefore, we expect a positive relation between enjoyment and WTP. To our knowledge, no previous studies include enjoyment in WTP research.

Based on this overview, the expected relations between the main predictive factors and WTP for sport and physical activity are summarised in Table 1.

\section{Methods}

\section{Participants}

We studied respondents' $\mathrm{WTP}_{\text {money }}$ and $\mathrm{WTP}_{\text {time }}$ in ongoing Dutch CBHEPA programs, summarised under the denominator 'communities on the move' (CoM). CoM was developed and disseminated by the Netherlands Institute for Sports and Physical Activity (NISB) from 2003 to 2012. Since 2012, there has been an on-going evaluation study of CoM (Herens et al. 2013). CBHEPA groups were recruited to participate in the evaluation study in collaboration with NISB and local CBHEPA program representatives (purposive sampling). CBHEPA groups were selected on the basis of their participants' socio-economic criteria (income, education, employment status). A total of 268 respondents were included, active in 19 CBHEPA groups (10-20 participants) distributed over seven Dutch municipalities. Assuming an average group size of 15 , the estimated response rate was $94 \%$.

\section{Data collection}

Standardised paper-and-pencil questionnaires were developed for evaluating CoM. Data collection for WTPmoney and $\mathrm{WTP}_{\text {time }}$ formed an integral part of the standardised questionnaire. $\mathrm{WTP}_{\text {money }}$ and $\mathrm{WTP}_{\text {time }}$ were measured using ordinal closed-ended questions. WTPmoney was measured as the maximum amount (in whole euro's) people were willing to spend monthly on sport and physical activity [nine-point scale: (1) 0 euro; (2) 1-5 euro; (3) 6-10 euro; ... (9) more than 35 euro, namely ....]. $\mathrm{WTP}_{\text {time }}$ was measured as the maximum time (in minutes) people were willing to spend on travel time to the sport venue (Pawlowski et al. 2009) [nine-point scale: (1) $0 \mathrm{~min}$; (2) 1-5 min; (3) 6-10 min; ... (9) more than $35 \mathrm{~min}$, namely ...]. The closed-ended data collection was chosen, based on the assumption that it provided 
Table 1 Summary of expectations for WTP for sport and physical activity

\begin{tabular}{|c|c|c|c|c|}
\hline Cluster & Predicting factor & $\begin{array}{l}\text { Known predictor for } \\
\text { health-related quality } \\
\text { of life and physical activity }\end{array}$ & $\begin{array}{l}\text { Known predictor WTP } \\
\text { health improvements }\end{array}$ & Expectation \\
\hline \multirow[t]{4}{*}{ Personal and socio-economic } & Income & + & $+/-$ & $\begin{array}{l}\text { 1. Income is positively related } \\
\text { to WTP money } \\
\text { and WTP }\end{array}$ \\
\hline & Educational level & + & + & $\begin{array}{l}\text { 2. Educational level is posi- } \\
\text { tively related to } \mathrm{WTP}_{\text {money }} \\
\text { and } \mathrm{WTP}_{\text {time }}\end{array}$ \\
\hline & Age & + & $+/-$ & $\begin{array}{l}\text { 3. Age is negatively related to } \\
\text { WTP } \text { money and WTP time }\end{array}$ \\
\hline & Ethnic origin & + & $?$ & $\begin{array}{l}\text { 4. Non-Dutch origin is nega- } \\
\text { tively related to } \mathrm{WTP}_{\text {money }} \\
\text { and } \mathrm{WTP}_{\text {time }}\end{array}$ \\
\hline \multirow[t]{4}{*}{ Health-related quality of life } & Perceived health status & + & + & $\begin{array}{l}\text { 5. Individual perceived health } \\
\text { status is positively related } \\
\text { to WTP } \text { money }_{\text {and }} \mathrm{WTP}_{\text {time }}\end{array}$ \\
\hline & Life satisfaction & + & $?$ & $\begin{array}{l}\text { 6. Life satisfaction is posi- } \\
\text { tively related to } \mathrm{WTP}_{\text {money }} \\
\text { and } \mathrm{WTP}_{\text {time }}\end{array}$ \\
\hline & Sense of coherence & + & $?$ & $\begin{array}{l}\text { 7. Sense of coherence is posi- } \\
\text { tively related to } \mathrm{WTP}_{\text {money }} \\
\text { and } \mathrm{WTP}_{\text {time }}\end{array}$ \\
\hline & Self-efficacy & + & $?$ & $\begin{array}{l}\text { 8. Self-efficacy is positively } \\
\text { related to WTP money and } \\
\text { WTP }_{\text {time }}\end{array}$ \\
\hline \multirow[t]{7}{*}{ Sport and physical activity } & Duration & + & $?$ & $\begin{array}{l}\text { 9. Duration of participation } \\
\text { in the CBHEPA program is } \\
\text { positively related to WTP- } \\
\text { money and WTP time }\end{array}$ \\
\hline & Frequency & + & $?$ & $\begin{array}{l}\text { 10. Frequency of participa- } \\
\text { tion is positively related to } \\
\text { WTP money and WTP time }\end{array}$ \\
\hline & Physical activity enjoyment & + & $?$ & $\begin{array}{l}\text { 11. Physical activity enjoy- } \\
\text { ment is positively related to } \\
\text { WTP money and WTP time }\end{array}$ \\
\hline & Leisure-time physical activity & + & $?$ & $\begin{array}{l}\text { 12. Additional leisure-time } \\
\text { physical activity is posi- } \\
\text { tively related to WTP money } \\
\text { and WTP time }\end{array}$ \\
\hline & Leisure time sport & + & $?$ & $\begin{array}{l}\text { 13. Additional leisure-time } \\
\text { sport is positively related to } \\
\text { WTP }_{\text {money }} \text { and WTP time }\end{array}$ \\
\hline & Sports club membership & + & + & $\begin{array}{l}\text { 14. (Former) sports club } \\
\text { membership is positively } \\
\text { related to WTP money and } \\
\text { WTP }_{\text {time }}\end{array}$ \\
\hline & Membership fee & $?$ & $?$ & $\begin{array}{l}\text { 15. Paying membership } \\
\text { fee is positively related to } \\
\text { WTP money }\end{array}$ \\
\hline
\end{tabular}

,+ known relation;,- known lack of relation; ?, unknown relation

for simplicity and uniformity, suitable for use in diverse socially vulnerable groups in CBHEPA programs.

Data on socio-economic indicators (age, income, education, employment status, living conditions) were measured in accordance with standardised questions of the Local and National Monitor Public Health in the Netherlands (National Institute for Public Health and the Environment (RIVM) 2005).
Health-related quality of life data were measured using: a visual analogue scale for perceived health (EQVAS), ranging from 0 to 100 (The EuroQol Group 1990); Cantril's ladder for life satisfaction, ranging from 0 to 10 (Cantril 1965; Peters et al. 2012); and the SoC threeitem, three-point scale for sense of coherence (Eriksson and Lindström 2005; Olsson et al. 2009). Questions were: 'Do you usually see solutions to problems and difficulties 
that other people find hopeless?' (manageability), 'Do you usually feel that your daily life is a source of personal satisfaction?' (meaningfulness) and 'Do you usually feel that the things that happen to you in your daily life are hard to understand?' (comprehensibility).

Sport and physical activity behaviour were measured using the validated Short Questionnaire for Sport and Physical Activity (SQUASH), measuring self-reported work-related, domestic, leisure-time and sport-related physical activities in minutes per week (Wendel-Vos et al. 2003; De Hollander et al. 2012). Physical activity enjoyment was measured using a nine-item, five-point scale, translated and adapted from the Physical Activity Enjoyment Scale (Mullen et al. 2011). Statements were for example: 'When I do exercise or sports, I enjoy it', or 'When I do exercise or sports, I feel bored'. Self-efficacy for physical activity behaviour was measured using a six-item, fivepoint scale (Bandura 2006). Statements were for example: 'I am confident that I am able to continue to participate in the physical activity program during the coming months', and 'I am confident that I am able to continue to participate in the physical activity program when I am tired'.

Questionnaires were individually filled in during or after a group training session at the sports venue. Informed consent was arranged orally on the spot and confirmed in writing. The researcher explained the purpose of the study at each session. Both the researcher and trained assistants helped respondents who had difficulty filling out the questionnaire by giving instructions or by adopting an interview style. The number of assistants varied with group composition: from one for groups with only Dutch native speakers to a maximum of five in groups with migrant respondents. Dutch was the working language, since ethnic diversity within groups was large ( $>10$ countries of origin). Interpretation, if needed, was provided by an assistant or a fellow group member from a similar background, sufficiently proficient in Dutch. Completion of the questionnaire took on average 30-35 min. After filling out the questionnaire, respondents received a small treat.

\section{Data analysis}

The dependent variables $\mathrm{WTP}_{\text {money }}$ and $\mathrm{WTP}_{\text {time }}$ were recoded into seven categories. Assumptions for normality were explored. The income variable was recoded and tested with a Pearson Chi square test to check for the assumption that it could be used as independent test variable, despite the fact that $28.1 \%$ of the respondents did not specify income (not knowing, not wanting to). There was no significant association between $\mathrm{WTP}_{\text {money }}$ categories and whether or not respondents had specified their income $\left(\chi^{2}=6.208 ; \mathrm{p}>0.05\right)$; this led to the conclusion that income could be used in the model.
The variables for age and education were recoded into categories, and assumptions for normality were checked. The scale variables Physical Activity Enjoyment Scale (Cronbach's $\alpha=0.87$ ) and self-efficacy (Cronbach's $\alpha=0.69$ ) were calculated, recoding each item into the same direction, and excluding system missing values. An ordered probit analysis was used (SPSS22) to assess factors predicting $\mathrm{WTP}_{\text {money }}$ and $\mathrm{WTP}_{\text {time }}$. The different expectations for $\mathrm{WTP}_{\text {money }}$ and $\mathrm{WTP}_{\text {time }}$ were tested, using $\mathrm{p}<0.10$ as the upper limit for statistical significance (Greene 2003; Jackson 2008).

The authors declare that the study was conducted in accordance with general ethical guidelines for behavioural and social research in the Netherlands. Participation was on a voluntary basis and guarantees of anonymity were given prior to each data collection session.

\section{Results}

\section{Descriptive statistics}

A total of 268 respondents were included, $86.6 \%$ women and $13.4 \%$ men, with a mean age of 58.6 years old ( $s d$ 14.0). One-third of the respondents (35.4\%) were of Dutch origin, $64.6 \%$ of non-Dutch origin, living on average 25.5 years in the Netherlands ( $s d 11.4$ ). About $25 \%$ had a household income $<€ 1000 /$ month, and $26.6 \%$ had a household income $<€ 1350 /$ month. Nearly half had low educational levels (48.6\%). The majority were not professionally employed (88.1\%).

Mean score on the health-related visual analogue scale (EQ-VAS scale 0-100) was 70.2 ( $s d 15.7$ ), indicating reasonably good perceived health. Mean score for life satisfaction (scale 0-10) was 7.8 ( $s d 1.5)$. Most participants had a weak $(34.3 \%)$ or moderate $(51.4 \%)$ SoC, and $14.3 \%$ had a strong SoC. Mean score on the scale for self-efficacy (scale 6-30) was 22.6 (sd 5.9), indicating fairly high levels of self-efficacy. Mean score on the Physical Activity Enjoyment Scale (scale 9-45) was 14.0 (sd 6.0), indicating high levels of physical activity enjoyment. About half of the respondents $(52.8 \%)$ participated $<3$ months in the CBHEPA programs, $47.2 \%$ participated more than 3 months. The majority $(68.9 \%)$ exercised once a week, $28.5 \%$ exercised more frequently. Fifty percent of the respondents paid a membership fee for the CBHEPA program, $50 \%$ participated for free (Table 2). Membership fees ranged from $€ 2.50$ to $€ 15.40$, with an average of $€ 6.95$ (sd $€ 4.64)$.

\section{Willingness to pay for sport and physical activity}

The average monthly $\mathrm{WTP}_{\text {money }}$ was $€ 9.6$ ( $s d$ 10.6) (Table 3). Variation in responses was fairly large. Over $16 \%$ of the respondents were not willing to pay at all for sport and physical activity, mostly respondents in free 
Table 2 Characteristics of WTP respondents

\begin{tabular}{|c|c|}
\hline Variable & Value \\
\hline \multicolumn{2}{|c|}{ Predictors relating to personal conditions } \\
\hline \multicolumn{2}{|l|}{ Gender $(n=268)$} \\
\hline Women & $86.6 \%$ \\
\hline Men & $13.4 \%$ \\
\hline \multicolumn{2}{|l|}{ Age $(n=253)$} \\
\hline Mean (sd) & $58.6(14.0)$ \\
\hline Range & $26.64-90.64$ \\
\hline \multicolumn{2}{|l|}{ Ethnic origin $(n=268)$} \\
\hline Dutch & $35.4 \%$ \\
\hline Non-Dutch ${ }^{a}$ & $64.6 \%$ \\
\hline \multicolumn{2}{|c|}{ Predictors relating to socio-economic conditions } \\
\hline \multicolumn{2}{|l|}{ Income $(n=256)$} \\
\hline$<€ 1000$ & $25.4 \%$ \\
\hline$€ 1001-€ 1350$ & $26.6 \%$ \\
\hline$€ 1351-€ 1800$ & $12.1 \%$ \\
\hline$>€ 1800$ & $7.8 \%$ \\
\hline Income not specified & $28.1 \%$ \\
\hline \multicolumn{2}{|l|}{ Education $(n=256)$} \\
\hline No/primary education & $48.6 \%$ \\
\hline Secondary education & $42.4 \%$ \\
\hline College/university education & $9.0 \%$ \\
\hline \multicolumn{2}{|c|}{ Predictors relating to health-related quality of life conditions } \\
\hline \multicolumn{2}{|l|}{ EQ-VAS $(0-100)(n=259)$} \\
\hline Mean (sd) & $70.24(15.74)$ \\
\hline Range & $0-100$ \\
\hline \multicolumn{2}{|l|}{ Life satisfaction $(0-10)(n=262)$} \\
\hline Mean (sd) & $7.78(1.49)$ \\
\hline Range & $1-10$ \\
\hline \multicolumn{2}{|c|}{ Sense of coherence (SoC3) $(n=245)$} \\
\hline Strong SoC (3) & $14.3 \%$ \\
\hline Moderate SoC (4-5) & $51.4 \%$ \\
\hline Weak SoC (6-9) & $34.3 \%$ \\
\hline \multicolumn{2}{|l|}{ Self-efficacy scale $(n=242)$} \\
\hline Mean (sd) & $22.56(5.85)$ \\
\hline Range & $8-30$ \\
\hline \multicolumn{2}{|c|}{ Predictors relating to sport and physical activity } \\
\hline \multicolumn{2}{|c|}{ Participation duration in CBHEPA program $(n=254)$} \\
\hline$<3$ months & $52.8 \%$ \\
\hline $3-6$ months & $15.4 \%$ \\
\hline$>6$ months & $31.9 \%$ \\
\hline \multicolumn{2}{|l|}{ Frequency $(n=267)$} \\
\hline$<1 \times$ week & $2.6 \%$ \\
\hline $1 \times$ week & $68.9 \%$ \\
\hline $2 \times$ week & $19.1 \%$ \\
\hline$>2 \times$ week & $9.4 \%$ \\
\hline \multicolumn{2}{|c|}{ Physical Activity Enjoyment Scale $(n=250)$} \\
\hline Mean (sd) & $14.04(5.98)$ \\
\hline Range & $9-44$ \\
\hline
\end{tabular}

Table 2 continued

\begin{tabular}{ll}
\hline Variable & Value \\
\hline (Former) sports club member $(\mathrm{n}=245)$ & \\
Yes & $59.2 \%$ \\
No & $40.8 \%$ \\
Leisure-time physical activity yes/no/ $\mathrm{n}=265)$ & \\
Yes & $85.3 \%$ \\
No & $14.7 \%$ \\
Leisure-time sport yes/no $(\mathrm{n}=264)$ & \\
Yes & $42.8 \%$ \\
No & $57.2 \%$ \\
Membership fee yes/no $(\mathrm{n}=267)$ & \\
Yes & $50.2 \%$ \\
No & $49.8 \%$ \\
\hline
\end{tabular}

a Number of countries of origin: 29

CBHEPA programs. A little over $25 \%$ were willing to pay to a maximum of $€ 5 /$ month, $45.5 \%$ between $€ 6$ and $€ 20$; $13.0 \%$ were willing to pay more than $€ 20$. The maximum $\mathrm{WTP}_{\text {money }}$ reported was $€ 80(\mathrm{n}=1)$. The average $\mathrm{WTP}_{\text {time }}$ was $17.6 \mathrm{~min}$ ( $s d 15.1$ ) single journey travel time (Table 3). Two-thirds reported a maximum willingness to travel of between 5 and $20 \mathrm{~min}$. The maximum $\mathrm{WTP}_{\text {time }}$ reported was $120 \min (n=1)$ to attend competition matches.

\section{Factors predicting willingness to pay for sport and physical activity}

The dependent ordinal variables $\mathrm{WTP}_{\text {money }}$ and $\mathrm{WTP}_{\text {time }}$ were entered in an ordered probit model in SPSS22. Predictors measured as ordinal or categorical variables were entered as factors, predictors measured as scale variables were entered as covariates. Cases with missing values were excluded from analysis.

As expected for $\mathrm{WTP}_{\text {money }}(\mathrm{n}=176)$, our findings showed that low income $(<€ 1000)$ was negatively related to $\mathrm{WTP}_{\text {money, }}$ whereas perceived health (EQ-VAS) was positively related to $\mathrm{WTP}_{\text {money }}$. We also found that duration (>3 months) and frequency of participation $(1 \times$ week or more), actual or former leisure-time sport participation, and physical activity enjoyment were positively related to $\mathrm{WTP}_{\text {money }}$ (Table 4).

Contrary to our expectations, we found no relationships between educational level or ethnic origin and $\mathrm{WTP}_{\text {money, }}$ between life satisfaction, self-efficacy or SoC and $\mathrm{WTP}_{\text {money }}$, and no relationship between leisure-time physical activity and WTP money (Table 4).

As expected for $\mathrm{WTP}_{\text {time }}(\mathrm{n}=172)$, our findings showed that low income $(<€ 1000)$ was negatively related to $\mathrm{WTP}_{\text {time }}$. Contrary to our expectations, age was positively related to $\mathrm{WTP}_{\text {time. }}$. People younger than 50 years of age were less willing to travel for a longer time than 
Table 3 WTP for sport and physical activity across groups

\begin{tabular}{|c|c|c|}
\hline Variable & Amount & Respondents (\%) \\
\hline \multirow{9}{*}{$\begin{array}{l}\text { WTP } \\
\quad(n=261)\end{array}$} & $€ 0$ & 16.4 \\
\hline & $€ 0-1$ & 3.1 \\
\hline & $€ 2-5$ & 22.1 \\
\hline & $€ 6-10$ & 19.5 \\
\hline & $€ 11-15$ & 16.8 \\
\hline & $€ 16-20$ & 9.2 \\
\hline & $>€ 20$ & 13.0 \\
\hline & Mean (sd) & $9.6(10.6)$ \\
\hline & Median & 7.5 \\
\hline \multirow{9}{*}{$\begin{array}{l}\text { WTP }_{\text {time }}(\mathrm{min} / \text { single-journey }) \\
\quad(\mathrm{n}=246)\end{array}$} & $0-1$ & 2.0 \\
\hline & $2-5$ & 6.4 \\
\hline & $6-10$ & 16.9 \\
\hline & $11-15$ & 27.7 \\
\hline & $16-20$ & 17.3 \\
\hline & $21-25$ & 7.2 \\
\hline & $>25$ & 22.5 \\
\hline & Mean (sd) & $17.6(15.1)$ \\
\hline & Median & 12.5 \\
\hline
\end{tabular}

people over 50 years of age. Contrary to our expectations, other personal and socio-economic predictors, the health-related and the sport and physical activity-related predictors did not seem relevant for predicting $\mathrm{WTP}_{\text {time }}$ (Table 4).

In sum, sport and physical activity program-related predictors were more relevant for predicting $\mathrm{WTP}_{\text {money }}$ than socio-economic or health predictors. Also, leisuretime physical activity did not seem relevant. For WTPtime only two of the socio-economic predictors, income and age, seemed to be relevant. Young age is related to lower $\mathrm{WTP}_{\text {time. }}$. The expectation is confirmed for the lowest income level $(<€ 1000)$ that income predicts WTP in terms of time and money. Educational level and ethnic origin seem unrelated to WTP, as well as sense of coherence, leisure-time physical activity, and paying membership fee (Table 5).

\section{Discussion}

We conducted this study to assess the WTP for sport and physical activity of participants in CBHEPA programs targeting socially vulnerable groups, expressed in money and time. Furthermore, we explored which factors predict WTP for sport and physical activity. We found relatively low $\mathrm{WTP}_{\text {money }}$ values, with a monthly average of $<€ 10$. This can be explained by the fact that around half of our study population represent, as intended, the lowest income levels in the Netherlands (Statistics Netherlands 2014). WTP research indicates that WTP is associated with a person's ability to pay, in other words, person's income (Donaldson 1999; Remonnay et al. 2008; Romé et al. 2010). The fact that particularly the lowest income category $(<€ 1000)$ relates negatively to WTP suggests that the association between WTP for sports and physical activity in higher income groups might be more strongly related to other factors.

Respondents' average $\mathrm{WTP}_{\text {time }}$ is around $17 \mathrm{~min}$ of single journey travel time. Our findings are consistent with other studies. A Dutch study reported a value for willingness to travel to sport facilities of $15 \mathrm{~min}$ (Prins et al. 2010). A German study reported values for willingness to travel ranging from 16 to $35 \mathrm{~min}$ among adult sports consumers (Pawlowski et al. 2009). This same study suggests that willingness to travel is related to type of sport and competition enrolment, and to how people prioritise their sport and physical activities.

In selecting variables to include in this study, we expected that predictors of health-related quality of life and physical activity behaviour would also predict WTP for sport and physical activity. However, we found several differences. As expected, the personal and socioeconomic predictors, income and age, are related to $\mathrm{WTP}_{\text {money }}$ Low income $(<€ 1000)$ is significantly negatively related to both $\mathrm{WTP}_{\text {money }}$ and $\mathrm{WTP}_{\text {time }}$. However, contrary to our expectations and findings of other studies (Krupnick et al. 2002), age ( $<50$ years) is negatively related to $\mathrm{WTP}_{\text {time. }}$. Probably, younger people face higher opportunity costs, i.e. benefits that could have been gained from an alternative use of the same resources (time and money) (Pampel et al. 2010), having to balance their time between household obligations, work, and leisure time. We did not find a relationship with other personal and socio-economic predictors, educational level or ethnic origin.

Of the health-related quality of life predictors, we found that perceived health is positively related to WTPmoney. This is consistent with other studies (Donaldson and Shackley 2003; Borghi and Jan 2008). We did not, however, find a relationship between WTP and life satisfaction, self-efficacy, and coping abilities (SoC). As mentioned before, we included these factors because they are well-known predictors of health-related quality of life and physical activity behaviour (Bauman et al. 2002; Hagger et al. 2002). Possibly, the reciprocal relationships between these factors have clouded our analysis used to study their relation to WTP for sport and physical activity.

Sport and physical activity-related predictors are most strongly related to $\mathrm{WTP}_{\text {money }}$-in particular how long and how often people participate in the program-and leisure-time sport experiences. On the basis of social cognitive theory, it can be argued that people who are 
Table 4 Ordered probit estimates of predictors for WTP for sport and physical activity

\begin{tabular}{|c|c|c|c|c|}
\hline Variable & $\begin{array}{l}\mathrm{WTP}_{\text {money }} \\
\text { Estimate }\end{array}$ & $\begin{array}{l}(n=176) \\
\text { sd }\end{array}$ & $\begin{array}{l}\text { WTP }_{\text {time }} \\
\text { Estimate }\end{array}$ & $\begin{array}{l}(n=172) \\
s d\end{array}$ \\
\hline \multicolumn{5}{|l|}{ Personal and socio-economic } \\
\hline \multicolumn{5}{|l|}{ Income } \\
\hline$<€ 1000$ & -0.750 & $0.434^{*}$ & 1.154 & $0.424^{* * *}$ \\
\hline$€ 1001-€ 1350$ & -0.027 & 0.413 & 0.374 & 0.404 \\
\hline$€ 1351-€ 1800$ & 0.302 & 0.499 & 0.100 & 0.496 \\
\hline$>€ 1800$ & 0.381 & 0.665 & 0.197 & 0.656 \\
\hline Not specified & Reference group & & Reference group & \\
\hline Educational level (low) & 0.040 & 0.315 & -0.442 & 0.314 \\
\hline \multicolumn{5}{|l|}{ Age } \\
\hline$<50$ years & -0.805 & 0.550 & -0.935 & $0.549^{*}$ \\
\hline $50-64$ years & -0.508 & 0.521 & 0.064 & 0.518 \\
\hline $65-75$ years & -0.0131 & 0.543 & 0.317 & 0.547 \\
\hline$>75$ years & Reference group & & Reference group & \\
\hline Ethnic origin (Dutch or non-Dutch) & -0.621 & 0.426 & 0.401 & 0.413 \\
\hline \multicolumn{5}{|l|}{ Health-related quality of life } \\
\hline EQ-VAS & 0.016 & $0.010^{*}$ & 0.013 & 0.010 \\
\hline Life satisfaction & 0.004 & 0.099 & 0.128 & 0.096 \\
\hline \multicolumn{5}{|l|}{ Sense of coherence (SoC3) } \\
\hline Weak SoC & 0.325 & 0.511 & -0.222 & 0.500 \\
\hline Moderate SoC & 0.250 & 0.478 & -0.302 & 0.457 \\
\hline Strong SoC & Reference group & & Reference group & \\
\hline Self-efficacy scale & -0.032 & 0.030 & 0.006 & 0.031 \\
\hline \multicolumn{5}{|l|}{ Sport and physical activity } \\
\hline \multicolumn{5}{|l|}{ Duration of participation } \\
\hline$<3$ months & -0.849 & $0.435^{*}$ & -0.181 & 0.391 \\
\hline $3-6$ months & -0.684 & 0.516 & 0.046 & 0.496 \\
\hline 6-12 months & 0.337 & 0.539 & -0.851 & 0.560 \\
\hline$>1$ year & Reference group & & Reference group & \\
\hline Physical Activity Enjoyment Scale & -0.048 & $0.026^{*}$ & 0.035 & 0.026 \\
\hline \multicolumn{5}{|l|}{ Frequency } \\
\hline$<1 \times$ week & -2.920 & $1.152^{* *}$ & -0.199 & 0.892 \\
\hline $1 \times$ week & -0.297 & 0.518 & -0.650 & 0.525 \\
\hline $2 \times$ week & -0.351 & 0.546 & -0.458 & 0.538 \\
\hline$>2 \times$ week & Reference group & & Reference group & \\
\hline Leisure-time physical activity (no) & -0.098 & 0.478 & -0.713 & 0.475 \\
\hline Leisure-time sport (no) & -0.604 & $0.315^{*}$ & -0.419 & 0.317 \\
\hline \multicolumn{5}{|l|}{ Sports club membership } \\
\hline (Former) member & -0.801 & $0.344^{* *}$ & -0.361 & 0.339 \\
\hline Never & Reference group & & Reference group & \\
\hline Membership fee (no) & -0.064 & 0.362 & - & - \\
\hline -2Log Likelihood & 548.914 & & 558.589 & \\
\hline Nagelkerke's pseudo $\mathrm{R}^{2}$ & 0.393 & & 0.199 & \\
\hline
\end{tabular}

${ }^{*} p<0.10$; ${ }^{* *} p<0.05$; ${ }^{* *} p<0.01$

or were members of a sports club haveknowledge of and experiences with sport. They might have more positive attributions to sport (Humpel et al. 2002; Nickel and Spink 2010) and are used to paying for sport (Higgins and Scholer 2009).
Our findings also indicate that respondents' $\mathrm{WTP}_{\text {money }}$ exceeds the actual membership fee by approximately one-third (€2.64). This suggests that socially vulnerable groups attribute positive value to sport and physical activity in CBHEPA programs (Morris et al. 2007). On 


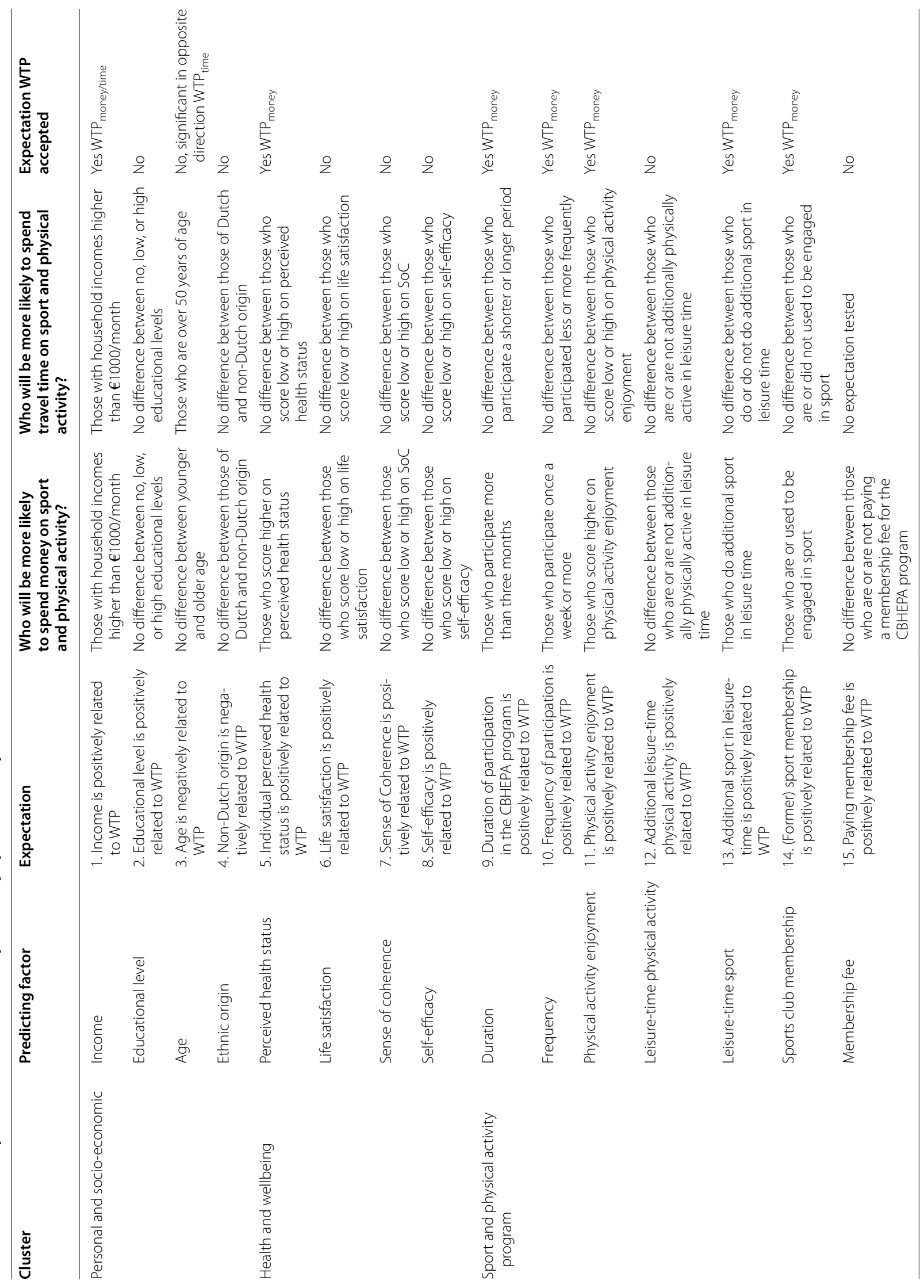


the other hand, we found a substantial percentage (16\%) of participants not willing to pay at all for sport and physical activity, in particular those enrolled in free CBHEPA programs. Future research could explore further whether or not respondents' characteristics differ between those who were willing to pay and those who were not.

It may be argued that short-term program satisfaction is probably more decisive for $\mathrm{WTP}_{\text {money }}$ than long-term perspectives of improved health. Our findings indicate a possible time preference effect, i.e. an individual's preference balancing between direct satisfaction from certain behaviour versus possible negative health consequences in the future (Jusot and Khlat 2013). Socially vulnerable groups generally show higher time preferences, focusing substantially on their wellbeing in the present, than high SES groups who place more emphasis on their wellbeing in the future (Chapman 2005). In this respect, our findings suggest that sport and physical activity program-related predictors best explain WTP for sport and physical activity, since these relate to actual physical activity experiences and short-term benefits. Physical activity enjoyment is an example of such a short-term benefit, as opposed to other positive health benefits (i.e. weight loss), which are future gains and therefore hard to predict (Dacey et al. 2003; Henderson 2009; Mullen et al. 2011). Our findings are consistent with research by Romé et al. (2010), who concluded that people report the highest WTP for immediate health improvements.

Assessment of WTP is presented in the health economics literature as a relatively easy method to study perceived benefits at individual level of health-related quality of life interventions in different communities and different contextual settings (Bayoumi 2004). Compared to assessing quality-adjusted life years (QALYs), estimating individual WTP has indeed some advantages, as stated in the literature: (1) WTP is theoretically grounded in welfare economics, (2) WTP does not need specification of which parts of the intervention need to be valued by respondents, and (3) WTP values express benefits in monetary terms (Donaldson et al. 1997; Olsen and Smith 2001; Shackley and Donaldson 2002). We faced, however, some methodological challenges in assessing WTP in socially vulnerable groups. First, about $16 \%$ of our respondents are not willing to pay for sport and physical activity, and the lowest income level is negatively related to WTP, indicating that answers are probably more reflective of people's actual income positions than of their willingness to pay (Hagberg and Lindholm 2006). As a result, our study might underestimate rather than overestimate $\mathrm{WTP}_{\text {money }}$ values. Second, Hagberg and Lindholm (2006) state that less educated respondents may show less understanding of the real and hypothetical situations as examined in WTP. This is consistent with our observations during the study, in which respondents occasionally seemed unable to distinguish between what they could afford and what they were willing to pay for sport and physical activity. It is also consistent with the negative relationship we found between WTP and low income. Third, respondents may have responded strategically in the hope that their answers would influence the actual pricing of their CBHEPA programs, as has been found in other studies (Smith 2003; Morris et al. 2007).

We addressed the methodological challenges by using closed-ended WTP questions. As the WTP data collection was integrated in a more comprehensive questionnaire to evaluate CBHEPA program outcomes, we tried to keep questions concerning different topics as concise and clear as possible, in view of our target group. Questionnaire use can be difficult in socially vulnerable groups. Lack of health literacy, lack of basic skills in reading and writing, and different beliefs about (health) concepts across cultures may lead to difficulties in understanding and interpreting the questions (Bonevski et al. 2014), eventually leading to non-response (Feskens et al. 2006). Our approach contributed to clarity and uniformity of data collection procedures within and between groups. In line with recommended procedures for WTP data collection, suggested by Smith (2003), offering the necessary specifications of the context and the service that people are valuing, our data collection in context, i.e. during the exercise class, contributes to the methodological robustness of our WTP study. On the other hand, our predefined WTP response categories may have limited people's choice. Group-wise data collection may also have had an impact on individual WTP responses.

\section{Conclusion}

Our assumptions that factors predicting health-related quality of life and WTP for health improvements may be relevant for predicting WTP for sport and physical activity are not unequivocally supported in this study. People from socially vulnerable groups, active in CBHEPA programs, are willing to pay for sport and physical activity, albeit low amounts. WTP in terms of money is significantly related to income and (former) experiences in sport and physical activity. WTP in terms of travel time is significantly related to income and age. Our findings for WTP for sport and physical activity are in line with studies reporting that WTP is not responsive to changes in health over time, indicating that health improvements over time do not simply result in a positive change in WTP (Harris et al. 2013). Income and short-term program satisfaction are probably more decisive for $\mathrm{WTP}_{\text {money }}$ than long-term perspectives of improving health-related quality of life. Awareness of 
these factors predicting WTP could contribute to future policy and development of CBHEPA programs, focusing on service provision to enhance people's behavioural competences for physical activity maintenance and program satisfaction rather than aiming at long-term health improvements.

\begin{abstract}
Abbreviations
CBHEPA: community-based health enhancing physical activity; CoM: communities on the move; CVM: contingent valuation method; EQ-VAS: EuroQoL visual analogue scale; NISB: Netherlands Institute for Sport and Physical Activity; QALY: quality-adjusted life years; SES: socio-economic status; SoC: sense of coherence; SQUASH: Short Questionnaire for Sport and Physical Activity; WTP: willingness to pay.
\end{abstract}

\section{Authors' contributions}

$\mathrm{MH}$ was the first author of the manuscript and conducted the study. JO and $\mathrm{MH}$ jointly conducted the analyses. All authors contributed to the drafting and revision of the manuscript. All authors read and approved the final manuscript.

\section{Author details}

'Social Sciences Group, Chair Group Health and Society, Wageningen University and Research, Hollandseweg 1, Postbus 8130, 6700 EW Wageningen, The Netherlands. ${ }^{2}$ Social Sciences Group, Chair Group Economics of Consumers and Households, Wageningen University and Research, Hollandseweg 1, Postbus 8130, 6700 EW Wageningen, The Netherlands.

\section{Acknowledgements}

The study is funded by ZonMw, the Netherlands Organisation for Health Research and Development (Project No. 50-51505-98-103). The Netherlands Institute for Sport and Physical Activity (NISB) developed the Communities on the Move program and is the collaborating agency. We express our appreciation to the experts who peer-reviewed the manuscript.

\section{Compliance with ethical guidelines}

\section{Competing interests}

The authors declare that they have no competing interests.

Received: 27 February 2015 Accepted: 10 September 2015 Published online: 19 September 2015

\section{References}

Antonovsky A (1996) The salutogenic model as a theory to guide health promotion. Health Promot Int 11(1):11-18. doi:10.1093/heapro/11.1.11

Bandura A (1995) Self-efficacy in changing societies. Cambridge University Press, Cambridge

Bandura A (2006) Guide for constructing self-efficacy scales. In: Pajares F, Urdan $T$ (eds) Self-efficacy beliefs of adolescents. Information Age Publishing Inc., pp 307-337

Bauman AE, Sallis JF, Dzewaltowski DA, Owen N (2002) Toward a better understanding of the influences on physical activity: the role of determinants, correlates, causal variables, mediators, moderators, and confounders. Am J Prev Med 23(2):5-14. doi:10.1016/S0749-3797(02)00469-5

Bayoumi AM (2004) The measurement of contingent valuation for health economics. Pharmacoeconomics 22(11):691-700. doi:10.2165/00019053-200422110-00001

Bonevski B, Randell M, Paul C, Chapman K, Twyman L, Bryant J, Brozek I, Hughes C (2014) Reaching the hard-to-reach: a systematic review of strategies for improving health and medical research with socially disadvantaged groups. BMC Med Res Methodol 14:42. doi:10.1186/1471-2288-14-42

Borghi J, Jan S (2008) Measuring the benefits of health promotion programmes: application of the contingent valuation method. Health Policy 87(2):235-248. doi:10.1016/j.healthpol.2008.01.004
Bos V, Kunst AE, Keij-Deerenberg IM, Garssen J, Mackenbach JP (2004) Ethnic inequalities in age-and cause-specific mortality in The Netherlands. Int $J$ Epidemiol 33(5):1112-1119. doi:10.1093/ije/dyh189

Bowling A (2005) Measuring health; a review of quality of life measurement scales, 3rd edn. Open University Press, Maidenhead

Cantril H (1965) The pattern of human concerns. Rutgers University Press, New Brunswick

Cawley J (2004) An economic framework for understanding physical activity and eating behaviors. Am J Prev Med 27(3, Supplement):117-125. doi:10.1016/j.amepre.2004.06.012

Centre for Policy-related Statistics (2013) Sport in beeld: De bijdrage van sport aan de Nederlandse economie in 2006, 2008 en 2010 [Sports in the picture: the contribution of sports to the Dutch economy in 2006, 2007 and 2010]. Statistics Netherlands, Den Haag/Heerlen

Chapman GB (2005) Short-term cost for long-term benefit: time preference and cancer control. Health Psychol 24(4S):S41. doi:10.1037/0278-6133.24.4.S41

Cockerham WC (2007) New directions in health lifestyle research. Int J Public Health 52(6):327-328. doi:10.1007/s00038-007-0227-0

Craig CL, Lambert EV, Inoue S, Alkandari JR, Leetongin G, Kahlmeier S (2012) The pandemic of physical inactivity: global action for public health. Lancet 380(9838):294-305

Crespo CJ, Smit E, Carter-Pokras O, Andersen R (2001) Acculturation and leisure-time physical inactivity in Mexican American adults: results from NHANES III, 1988-1994. Am J Prev Med 91(8):1254-1257. doi:10.2105/ AJPH.91.8.1254

Dacey M, Baltzell A, Zaichkowsky L (2003) Factors in women's maintenance of vigorous or moderate physical activity. Women Sport Phys Act J 12(1):87-111

De Hollander EL, Zwart L, de Vries SI, Wendel-Vos W (2012) The SQUASH was a more valid tool than the OBiN for categorizing adults according to the Dutch physical activity and the combined guideline. J Clin Epidemiol 65(1):73-81. doi:10.1016/j.jclinepi.2011.05.005

De Wit GA, Tariq L, Van Gils PF, Panneman MJM (2010) Over euro en effect: handleiding voor economisch evaluatieonderzoek bij gezondheidsbevordering [About euro and impact: manual for economic evaluation in health promotion]. Consumer Safety Institute, Arnhem

Dijst M, Vidakovic V (2000) Travel time ratio: the key factor of spatial reach. Transportation 27(2):179-199. doi:10.1023/a:1005293330869

Donaldson C (1999) Valuing the benefits of publicly-provided health care: does 'ability to pay' preclude the use of 'willingness to pay'? Soc Sci Med 49(4):551-563. doi:10.1016/50277-9536(99)00173-2

Donaldson C, Shackley P (2003) Willingness to pay for health care. In: Scott A, Maynard A, Elliott R (eds) Advances in health economics. Wiley Online Library, Sussex

Donaldson C, Farrar S, Mapp T, Walker A, Macphee S (1997) Assessing community values in health care: is the 'willingness to pay' method feasible? Health Care Anal 5(1):7-29. doi:10.1007/BF02678452

Downward P, Rasciute S (2011) Does sport make you happy? An analysis of the well-being derived from sports participation. Int Rev Appl Econ 25(3):331-348. doi:10.1080/02692171.2010.511168

Drummond MF, Sculpher MJ, Torrance GW, O'Brien BJ, Stoddart GL (2005) Methods for the economic evaluation of health care programmes. Oxford University Press, New York

Eriksson M, Lindström B (2005) Validity of Antonovsky's sense of coherence scale: a systematic review. J Epidemiol Commun Health 59(6):460-466 doi:10.1136/jech.2003.018085

Eriksson M, Lindström B (2007) Antonovsky's sense of coherence scale and its relation with quality of life: a systematic review. J Epidemiol Commun Health 61(11):938-944. doi:10.1136/jech.2006.056028

Feskens R, Hox J, Lensvelt-Mulders G, Schmeets H (2006) Collecting data among ethnic minorities in an international perspective. Field Method 18(3):284-304. doi:10.1177/1525822×06288756

GAPA (2012) WHO monitoring framework and targets for the prevention and control of NCDs; position statement \#2 support for the inclusion of a global target on physical activity. Global Advocacy for Physical Activity (GAPA)

Greene WH (2003) Econometric analysis, 5th edn. Prentice Hall International, Upper Saddle River

Hagberg LA, Lindholm L (2006) Review article: cost-effectiveness of healthcare-based interventions aimed at improving physical activity. Scand J Public Health 34(6):641-653. doi:10.1080/14034940600627853 
Hagger MS, Chatzisarantis NLD, Biddle SJH (2002) A meta-analytic review of the theories of reasoned action and planned behavior in physical activity: predictive validity and the contribution of additional variables. J Sport Exerc Psychol 24(1):3-32

Harris A, Youd J, Buchbinder R (2013) A comparison of directly elicited and pre-scored preference-based measures of quality of life: the case of adhesive capsulitis. Qual Life Res 22(10):2963-2971. doi:10.1007/ s11136-013-0415-8

Hawe P, Shiell A (2000) Social capital and health promotion: a review. Soc Sci Med 51(6):871-885. doi:10.1016/S0277-9536(00)00067-8

Henderson KA (2009) A paradox of sport management and physical activity interventions. Sport Man Rev 12(2):57-65. doi:10.1016/j.smr.2008.12.004

Herens M, Wagemakers A, Vaandrager L, Van Ophem J, Koelen M (2013) Evaluation design for community-based physical activity programs for socially disadvantaged groups - the case of communities on the move. JMIR Res Proc. doi:10.2196/resprot.2327

Higgins ET, Scholer AA (2009) Engaging the consumer: the science and art of the value creation process. J Consum Psychol 19(2):100-114. doi:10.1016/j.jcps.2009.02.002

Hildebrandt V, Bernaards C, Stubbe J (2013) Trend report physical activity and health 2010/2011. TNO Innovation for Life, Leiden

Humpel N, Owen N, Leslie E (2002) Environmental factors associated with adults' participation in physical activity: a review. Am J Prev Med 22(3):188-199. doi:10.1016/S0749-3797(01)00426-3

Jackson D (2008) The significance level of meta-regression's standard hypothesis test. Commun Stat 37(10):1576-1590. doi:10.1080/03610920801893863

Johannesson M, Johansson PO (1997) Quality of life and the WTP for an increased life expectancy at an advanced age. J Public Econ 65(2):219228. doi:10.1016/S0047-2727(97)00014-5

Johnson BK, Whitehead JC, Mason DS, Walker GJ (2007) Willingness to pay for amateur sport and recreation programs. Contemp Econ Policy 25(4):553-564. doi:10.1111/j.1465-7287.2007.00072.x

Jusot F, Khlat M (2013) The role of time and risk preferences in smoking inequalities: a population-based study. Addict Behav 38(5):2167-2173. doi:10.1016/j.addbeh.2012.12.011

Klose T (1999) The contingent valuation method in health care. Health Policy 47(2):97-123. doi:10.1016/S0168-8510(99)00010-X

Krupnick A, Alberini A, Cropper M, Simon N, O'Brien BJ, Goeree R, Heintzelman M (2002) Age, health and the willingness to pay for mortality risk reductions: a contingent valuation survey of Ontario residents. J Risk Uncertain 24(2):161-186. doi:10.1023/A:1014020027011

Kyle GT, Absher JD, Hammitt WE, Cavin J (2006) An examination of the motivation-involvement relationship. Leis Sci 28(5):467-485. doi:10.1080/01490400600851320

Lehnert K, Sudeck G, Conzelmann A (2012) Subjective well-being and exercise in the second half of life: a critical review of theoretical approaches. Eur Rev Aging Phys Act 9(2):87-102. doi:10.1007/s11556-012-0095-3

Lindström M, Hanson BS, Östergren P-O (2001) Socioeconomic differences in leisure-time physical activity: the role of social participation and social capital in shaping health related behaviour. Soc Sci Med 52(3):441-451. doi:10.1016/S0277-9536(00)00153-2

López-Mosquera N, Sánchez M (2013) Direct and indirect effects of received benefits and place attachment in willingness to pay and loyalty in suburban natural areas. J Environ Psychol 34:27-35. doi:10.1016/j. jenvp.2012.11.004

Lorgelly PK, Lawson KD, Fenwick EAL, Briggs AH (2010) Outcome measurement in economic evaluations of public health interventions: a role for the capability approach? Int J Environ Res Pub Health 7(5):2274-2289. doi:10.3390/ijerph7052274

Marcus BH, Selby VC, Niaura RS, Rossi JS (1992) Self-efficacy and the stages of exercise behavior change. Res Q Exerc Sport 63(1):60-66. doi:10.1080/027 01367.1992.10607557

McAuley E, Blissmer B (2000) Self-efficacy determinants and consequences of physical activity. Exerc Sport Sci Rev 28(2):85-88

McCarville RE (1991) An empirical investigation of the influence of cost information on willingness to pay for public aerobics classes. Leis Sc 13(2):85-96. doi:10.1080/01490409109513128

Ministry of Health Welfare and Sports (2006) Samen voor sport [together for sport]. Implementation program 2006-2010. Ministry of Health Welfare and Sports, Den Haag
Ministry of Health Welfare and Sports (2012) Sport en bewegen in de buurt [sport and physical activity in the neighbourhood]. Ministry of Health Welfare and Sports. http://www.sportindebuurt.nl/buurtsportcoaches/ wat-zijn-buurtsportcoaches/. Accessed 02 Dec 2014

Morris S, Devlin N, Parkin D (2007) Economic analysis in health care. Wiley, Chichester

Mullen SP, Olson EA, Phillips SM, Szabo AN, Wójcicki TR, Mailey EL, Gothe NP, Fanning JT, Kramer AF, McAuley E (2011) Measuring enjoyment of physical activity in older adults: invariance of the Physical ACtivity Enjoyment Scale (PACES) across groups and time. Int J Behav Nutr Phy 8(1):103. doi:10.1186/1479-5868-8-103

Murphy SM, Edwards RT, Williams N, Raisanen L, Moore G, Linck P, Hounsome N, Din NU, Moore L (2012) An evaluation of the effectiveness and cost effectiveness of the National Exercise Referral Scheme in Wales, UK: a randomised controlled trial of a public health policy initiative. J Epidemiol Commun Health 66(8):745-753. doi:10.1136/ jech-2011-200689

National Institute for Public Health and the Environment (RIVM) (2005) Local and national health monitor. National Institute for Public Health and the Environment (RIVM). https://www.monitorgezondheid.nl/. Accessed 24 Sept 2014

Nickel D, Spink KS (2010) Attributions and self-regulatory efficacy for health-related physical activity. J Health Psychol 15(1):53-63. doi:10.1177/1359105309345172

Olsen JA, Smith RD (2001) Theory versus practice: a review of 'willingness to pay' in health and health care. Health Econ 10(1):39-52. doi:10.1002/1099-1050(200101)10:1<39:AID-HEC563>3.0.CO;2-E

Olsen JA, Donaldson C, Pereira J (2004) The insensitivity of willingness-to-pay to the size of the good: new evidence for health care. J Econ Psychol 25(4):445-460. doi:10.1016/S0167-4870(03)00029-1

Olsson M, Gassne J, Hansson K (2009) Do different scales measure the same construct? Three sense of coherence scales. J Epidemiol Commun Health 63(2):166-167. doi:10.1136/jech.2007.063420

Pampel FC, Krueger PM, Denney JT (2010) Socioeconomic disparities in health behaviors. Annu Rev Sociol 36(August):349. doi:10.1146/annurev. soc.012809.102529

Pawlowski T, Breuer C, Wicker P, Poupaux S (2009) Travel time spending behaviour in recreational sports: an econometric approach with management implications. Eur Sport Manag Q 9(3):215-242. doi:10.1080/16184740903023971

Peters LL, Boter H, Buskens E, Slaets JPJ (2012) Measurement properties of the Groningen frailty indicator in home-dwelling and institutionalized elderly people. J Am Med Dir Assoc 13(6):546-551. doi:10.1016/j. jamda.2012.04.007

Post NAM, de Bekker-Grob EW, Mackenbach JP, Slobbe LCJ (2010) Kosten van preventie in Nederland 2007 [costs of prevention in the Netherlands 2007]. National Institute for Public Health and the Environment (RIVM), Bilthoven

Prins RG, van Empelen P, te Velde SJ, Timperio A, van Lenthe FJ, Tak NI, Crawford D, Brug J, Oenema A (2010) Availability of sports facilities as moderator of the intention-sports participation relationship among adolescents. Health Educ Res 25(3):489-497. doi:10.1093/her/cyq024

Putnam RD (2000) Bowling alone. Simon and Schuster, New York

Remonnay R, Havet N, Morelle M, Carrère MO (2008) Analyzing the determinants of willingness-to-pay values for testing the validity of the contingent valuation method: application to home care compared to hospital care, vols 08-20. HAL Open Archives, Écully

Rhodes RE, Courneya KS, Blanchard CM, Plotnikoff RC (2007) Prediction of leisure-time walking: an integration of social cognitive, perceived environmental, and personality factors. Int J Behav Nutr Phy 4(1):51. doi:10.1186/1479-5868-4-51

Romé A, Persson U, Ekdahl C, Gard G (2010) Willingness to pay for health improvements of physical activity on prescription. Scand J Public Health 38(2):151-159. doi:10.1177/1403494809357099

Ross CE, Wu CL (1995) The links between education and health. Am Sociol Rev 60(5):719-745

Rütten A, Abel T, Kannas L, Von Lengerke T, Lüschen G, Diaz JAR, Vinck J, Van der Zee J (2001) Self reported physical activity, public health, and perceived environment: results from a comparative European study. J Epidemiol Commun Health 55(2):139-146. doi:10.1136/ jech.55.2.139 
Shackley P, Donaldson C (2002) Should we use willingness to pay to elicit community preferences for health care? New evidence from using a'marginal' approach. J Health Econ 21(6):971-991. doi:10.1016/ S0167-6296(02)00052-8

Skinner J, Zakus DH, Cowell J (2008) Development through sport: building social capital in disadvantaged communities. Sport Man Rev 11(3):253275. doi:10.1016/S1441-3523(08)70112-8

Smith RD (2003) Construction of the contingent valuation market in health care: a critical assessment. Health Econ 12(8):609-628. doi:10.1002/hec.755

Statistics Netherlands (2014) Welvaart in Nederland 2014 [prosperity in the Netherlands]. Statistics Netherlands, Heerlen

The EuroQol Group (1990) EuroQol: new facility for the measurement of health-related quality of life. Health Policy 16(3):199-208

Van Stralen MM, De Vries H, Mudde AN, Bolman C, Lechner L (2009) Determinants of initiation and maintenance of physical activity among older adults: a literature review. Health Psychol Rev 3(2):147-207. doi:10.1080/17437190903229462
Victoor A, Delnoij DMJ, Friele RD, Rademakers JJDJM (2012) Determinants of patient choice of healthcare providers: a scoping review. BMC Health Serv Res 12(1):272. doi:10.1186/1472-6963-12-272

Wendel-Vos GCW, Schuit AJ, Saris WHM, Kromhout D (2003) Reproducibility and relative validity of the short questionnaire to assess health-enhancing physical activity. J Clin Epidemiol 56(12):1163-1169. doi:10.1016/ s0895-4356(03)00220-8

Wendel-Vos G, Dutman AE, Verschuren W, Ronckers ET, Ament A, van Assema P, van Ree J, Ruland EC, Schuit AJ (2009) Lifestyle factors of a five-year community-intervention program: the Hartslag Limburg intervention. Am J Prev Med 37(1):50-56. doi:10.1016/j.amepre.2009.03.015

WHO (2006) Physical activity and health in Europe: evidence for action. WHO Regional Office for Europe, Copenhagen

WHO (2012) Comprehensive global monitoring framework and voluntary global targets for the prevention and control of NCDs. World Health Organisation. http://www.who.int/nmh/events/2011/consultation_ dec_2011/WHO_Discussion_Paper_FINAL.pdf. Accessed 24 Sept 2014

\section{Submit your manuscript to a SpringerOpen ${ }^{\odot}$ journal and benefit from:}

- Convenient online submission

- Rigorous peer review

- Immediate publication on acceptance

- Open access: articles freely available online

- High visibility within the field

- Retaining the copyright to your article

Submit your next manuscript at $>$ springeropen.com 